\title{
Good Governance: Enhancing and Poverty Reduction in Cambodia
}

\author{
VAY Lundy* LU Xinhai \\ College of Public Administration, Huazhong University of Science, and Technology, Wuhan, P.R. China \\ E-mail of the corresponding author: didi.lv168@gmail.com
}

\begin{abstract}
Cambodia has been growing rapidly over the few decades. Cambodia has enjoyed the fastest-growing economies and has sustained an average growth rate of $8 \%$ between 1998 and 2018 but poverty continues to fall in Cambodia. The poverty rate was $13.5 \%$ in 2014 compared to $47.8 \%$ in 2007 . And about $90 \%$ of the poor live in the countryside. Poverty Reduction is arithmetically a function of economic growth rates and income distribution and changes in income distribution. This research aims to provide how to promote good governance for sustainable development in Cambodia. It examines the key issues related to governance structures and national reforms to enhance good governance. The analysis and findings from this research aim to contribute insights for policy-making by the Royal Government of Cambodia
\end{abstract}

Keywords: Good Governance, Poverty Reduction, Enhance, Reform, Cambodia

DOI: $10.7176 / \mathrm{PPAR} / 10-6-04$

Publication date:June 30th 2020

\section{Introduction}

1.1 Brief Background

"Reforms are a life and death issue for Cambodia"

-Prime Minister Samdech HUN SEN

"Good Governance is the most important precondition to economic development with sustainability, equity and social justice. Good Governance requires wide participation, enhanced sharing of information, accountability, transparency, equality, inclusiveness and the rule of law. Good Governance requires that corruption be reduced to minimum, the views of minorities and the voices of the most vulnerable in society be fully heard and considered in decision making process."

-The Rectangular Strategy 2004 of the Royal Government of Cambodia

Good Governance (GG) is an increasingly important development issue in Cambodia. GG is emerging as one of the key strategies to sustain social and economic development in Cambodia (CDRI, 2000).

Governance is the way in which public power and authority is formed and used to manage the society's resource. GG rests on 4 pillars: accountability, transparency, predictability, and participation (World Bank, 2000).

Governance is defined as the manner in which power is exercised in the management of a country's economic and social resource for development (ADB (1995).

GG by the RGC mainly focuses on the four reforms such as: (a) judicial and legal reform; (b) public administration reform; (c) anti-corruption reform; and (d) Royal Cambodian Armed Forces reform (Cambodia, 2004-2008; 2008-2013; 2013-2018).

The formation of the RGC "A Coalition Government" in 1993 allowed Cambodia to stabilize the economy, restore the economic growth, and begin reforms to transform the economy into the market-oriented one.

The main objective of this study is to support the efforts of the Royal Government of Cambodia to enhance governance and reduce the poverty and for the sustainable development.

\subsection{Research Purpose}

This research is focus and studies on GG and PR in Cambodia. This study aims to provide a vital and objective basis for formulating policies for enhancing GG and to reduce the poverty in Cambodia. Furthermore, this paper will provide the recommendations and some strategies to government, researchers, and Cambodia's policy-makers to presumably understand how important good governance is towards the public improvement.

\subsection{Research Methodology}

This study was conducted in Cambodia and China. It uses primary data and secondary data which collected. Therefore, the survey results should always be taken in perspective. The surveys provide a reliable representation of the views and quantitative estimates of those who responded-but they can't access the level of knowledge or honesty of each respondent, nor can they represent information withheld from the interviewer.

Questionnaires survey data were collected from direct survey and online. By the way, the direct questionnaires survey also collected from people directly such as: citizen, students, university scholars, private sector staffs, NGO 
Staffs, government officials and so on who has completed on my questionnaires forms.

The most important information also received from interviewing with government officials from different institutions and ministries such as Senate of Cambodia, National Assembly, Ministry of Interior, Ministry of Planning, Ministry of Economic and Finance, Office of the Council of Ministers, etc. The surveys were conducted in circumstances designed to elicit the candid and reliable results.

Figure 1: Cambodia Good Governance Enhancing and Poverty Reduction Survey Sample Distribution Distribution of Household Sample

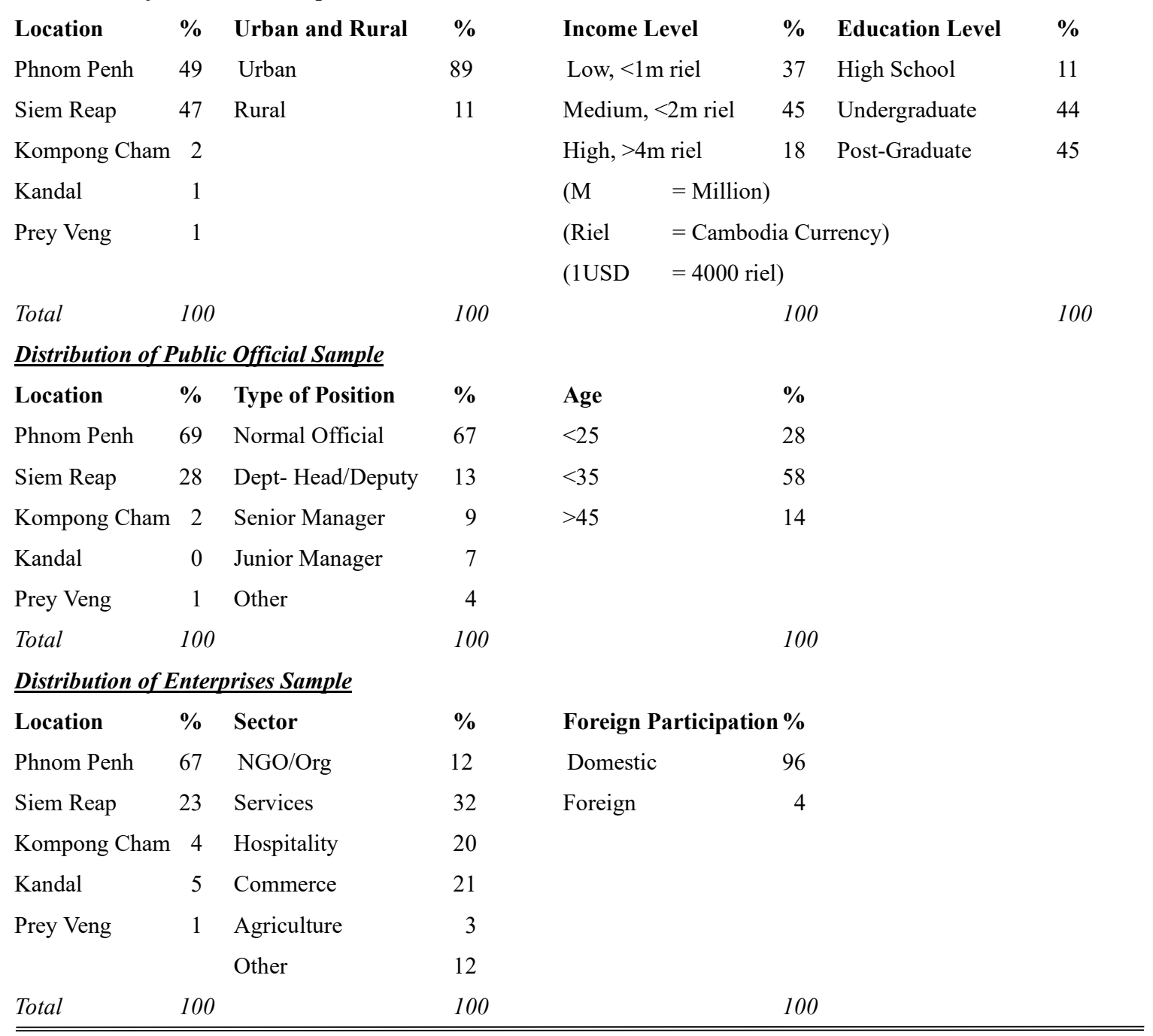

\section{Literature Review}

\subsection{General Definitions}

GG is, among other things, participatory, transparent and accountable, effective and equitable, and it promotes the rule of law. It ensures that political, social and economic priorities are based on broad consensus in society and those voices of the poorest and the most vulnerable are heard in decision-making over the allocation of the development resources (UNDP, 1997).

GG promotes equity, participation, pluralism, transparency, accountability, and the rule of law in an effective, efficient, and enduring way. In putting these principles into practice, we can see the holding of free, fair, and frequent elections, representative legislatures that make laws and provide oversight, and an independent judiciary to interpret those laws. The greatest threats to GG come from corruption, violence, and poverty, all of which undermine transparency, security, participation, and fundamental freedoms (UN, 2013).

GG reforms aim to promote governance capabilities that are market-enhancing: they aim to make markets more efficient by reducing transaction costs. To the extent that these reforms can be implemented they are likely to improve market outcomes in developing countries. 


\subsection{Four Pillars of Good Governance}

According to the World Bank, the instrumental nature governance, however, implies that the following four governance pillars are universally applicable regardless of the economic orientation, strategic priorities, or policy choices of the government. The four components of governance are:

Accountability is the capacity to call officials to account for their actions. Effective accountability has two components: "answerability" and "consequences". "Answerability" is the requirement to respond periodically to questions concerning one's official action. There is also a need for predicable and meaningful "Consequences", without which accountability is only a time consuming formality. In addition, both of internal and external accountability are needed. Particularly under the dramatic improvements in information and communication technology, external accountability through feedback from service users and the citizenry can now be obtained at low cost and for a greater variety of government activities, and is an essential adjunct to improving efficiency and effectiveness of public service delivery.

Transparency entails low cost access to relevant information. Reliable and timely economic information is a must for the public (normally through the filter of responsible media). It is essential not only that information be provided, but also that it be relevant and understandable.

Predictability results primarily from laws and regulations that are clear, know in advance, and uniformly and effectively enforced. Lack of predictability makes it difficult for the public officials to plan for the provision of services. Predictability of government economic actions is also needed as an indicator on which the private sector can rely to make its own production, marketing and investment decisions. Most importantly to be predictable, the application of economic regulations must be effective, fair, and uniform.

Participation is needed to obtain reliable information and to serve as a reality check and watchdog for government action. Among other things, participation by external entities is needed as a spur to government operational efficiency, and feedback by users of public services is necessary for monitoring access to and quality of the services.

\subsection{The Links between Good Governance and Poverty Reduction}

Making the linkage between good strategies for poverty reduction and improvements better governance is essential to the success of country's target. The empirical research in a number of countries establishes that where there is weak governance this reinforces poverty (Narayan, 2000). A linkage was established by Knack and Keefer in their research between measures of trust and civic cooperation and economic growth.

The impact of poor standards of governance in fact usually falls most heavily on the poor. Poor people are generally excluded from the institutions that put in place plans, policies and rues determinative of their rights and obligations; that make decisions that affect their lives; and which allocate and administer public resources to programs affecting them. Whether it is through inefficient service delivery; through unfavorable policy settings; through inappropriate allocations of publics resources away from socially useful good such as education; through corruption; or through inability to enforce their legal rights-the poor are often the most adversely affected by poor governance. Unlike people on higher incomes, poor people often lack the power and resources to respond effectively to weak governance (World Bank, 2000).

Figure 2: Linkages in Poverty Reduction (ADB, 2000)

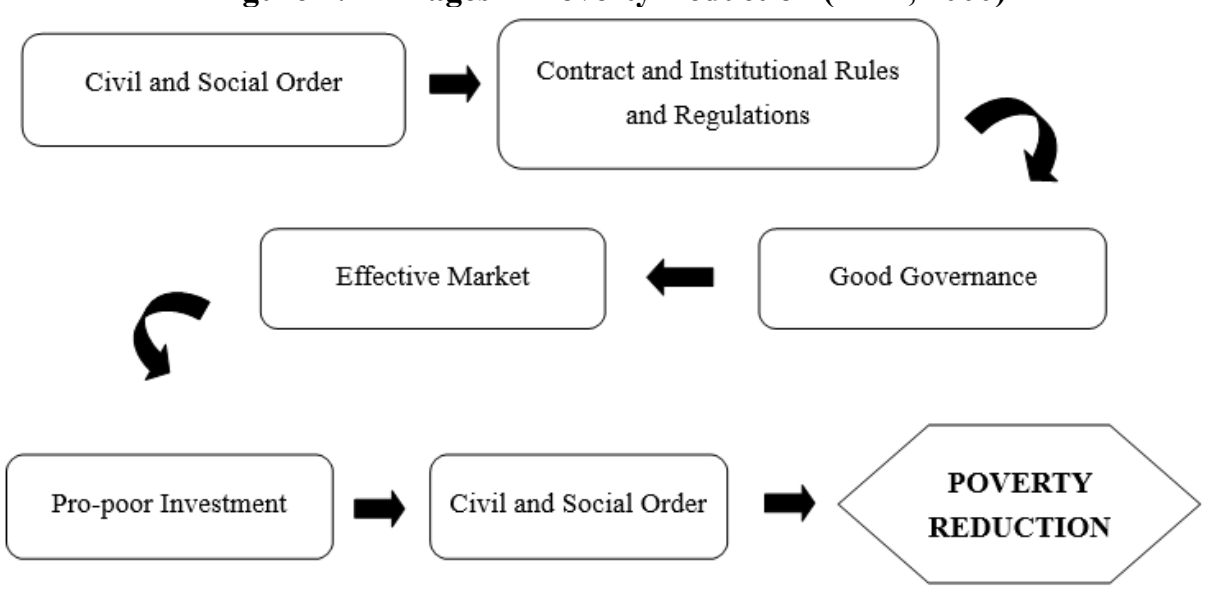

The figure 2 above developed by ADB, shows that PR rests on a foundation of civil and social order, GG, and institutional rules, effective markets, and pro-poor growth and focused poverty intervention. Weakness toward the bottom of this framework, such as weak governance, hurt the poor in two broad ways: the first, they weaken the effectiveness of markets, and thus hold down economic growth. Cross national research has shown that growth in the overall economy is on average accompanied by the same growth in the income of the poor (Kraay, 2000). 
Without strong growth, there is less chance to reduce poverty; and the second, weak governance hurts the poor through non-economic channels. Growth and human development doesn't automatically trickle down to benefit the poor. This needs to empower the poor, by targeting the structures that create poverty. The quality of governance at the central and local level is often the crucial link to make PR effective.

According to the ADB 1999, the implementation of a range of strategies for PR, which includes the improvement of governance as an integral and critical part, is thus required to overcome the disadvantage suffered by the poor. The work of donor agencies also suggests that in pursuing the range of strategies that are needed for PR, one main pillar must be improvement in governance. By way of the sample of figure 3 below describes the three strategic pillar approach taken.

Figure 3: ADB's Poverty Reduction Strategy ADB Operational Strategy

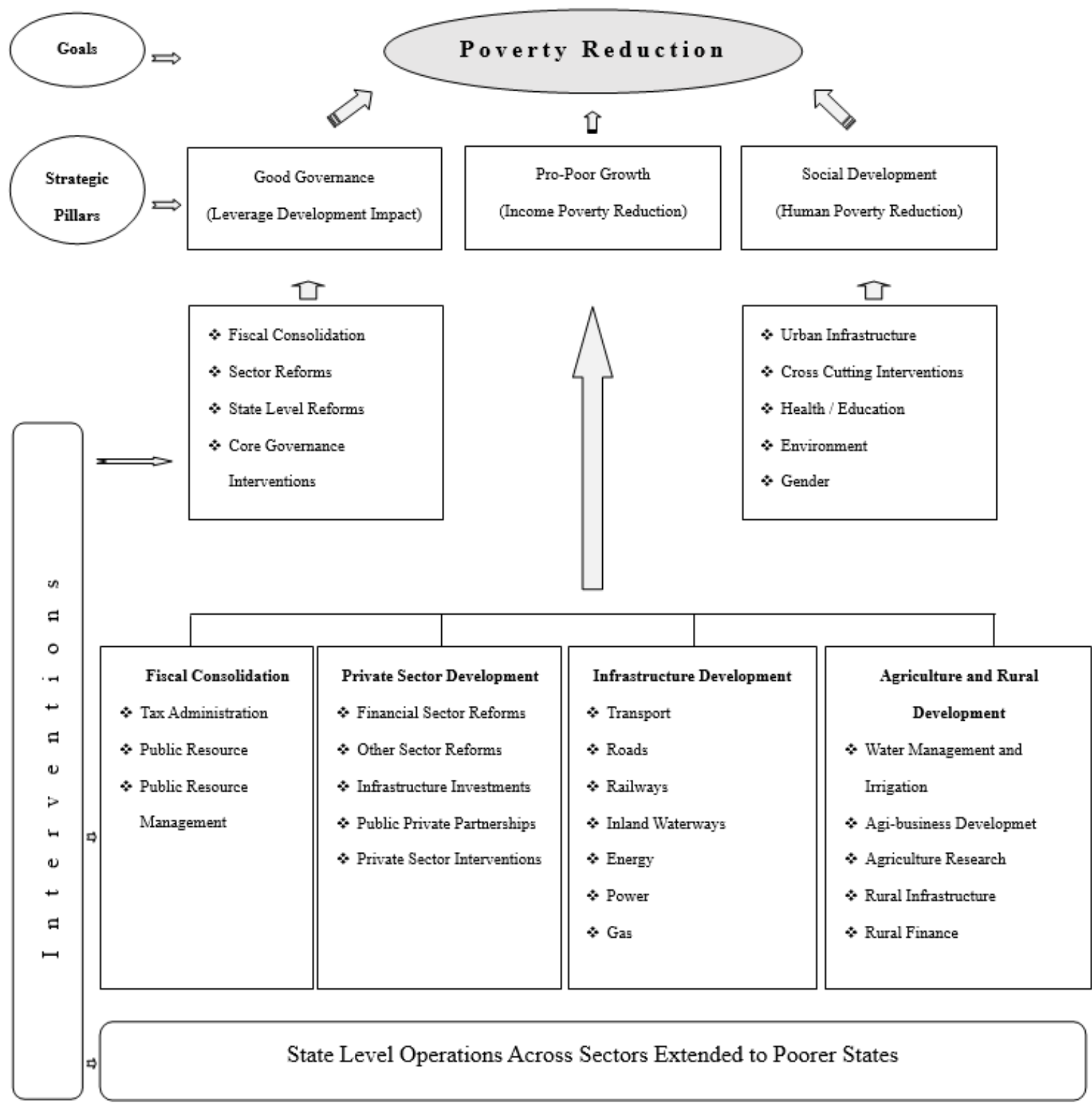

\subsection{Linking Governance, Growth, Redistribution, and Poverty Reduction}

A wide range of contradictory causal relationships has been suggested between growth and redistribution. The causal relationships relevant to particular countries are nevertheless important because higher growth may require either policy to slow down or reverse improvements in distribution or policy to improve the income distribution. The causal relationships between distribution and growth relevant to a particular country have significant implications for PR. For instance, if improvements in distribution have a negative impact on growth, an excessive focus on redistribution may have negative growth effects that could more than offset against the positive 
redistribution effects for PR.

The causality between growth and redistribution can also run in both directions. Growth may, in turn, have causal effects on distribution either positively or negatively, and again, there are obvious implications for PR. Finally, both growth and distribution are likely to be responsive to policy, and these policies can be judged in terms of their impacts on growth and redistribution. In turn, both growth and income distribution can determine the effectiveness of specific policies because the political feasibility of implementing particular policies may depend on the environment of growth and distribution (Khan, 2008).

The figure 4 below summarized the independencies among growth, redistribution and policy with reference to strategies of implementing GG reforms.

Figure 4: Causal links among governance, growth, redistribution, and Poverty Reduction (Khan, 2009)

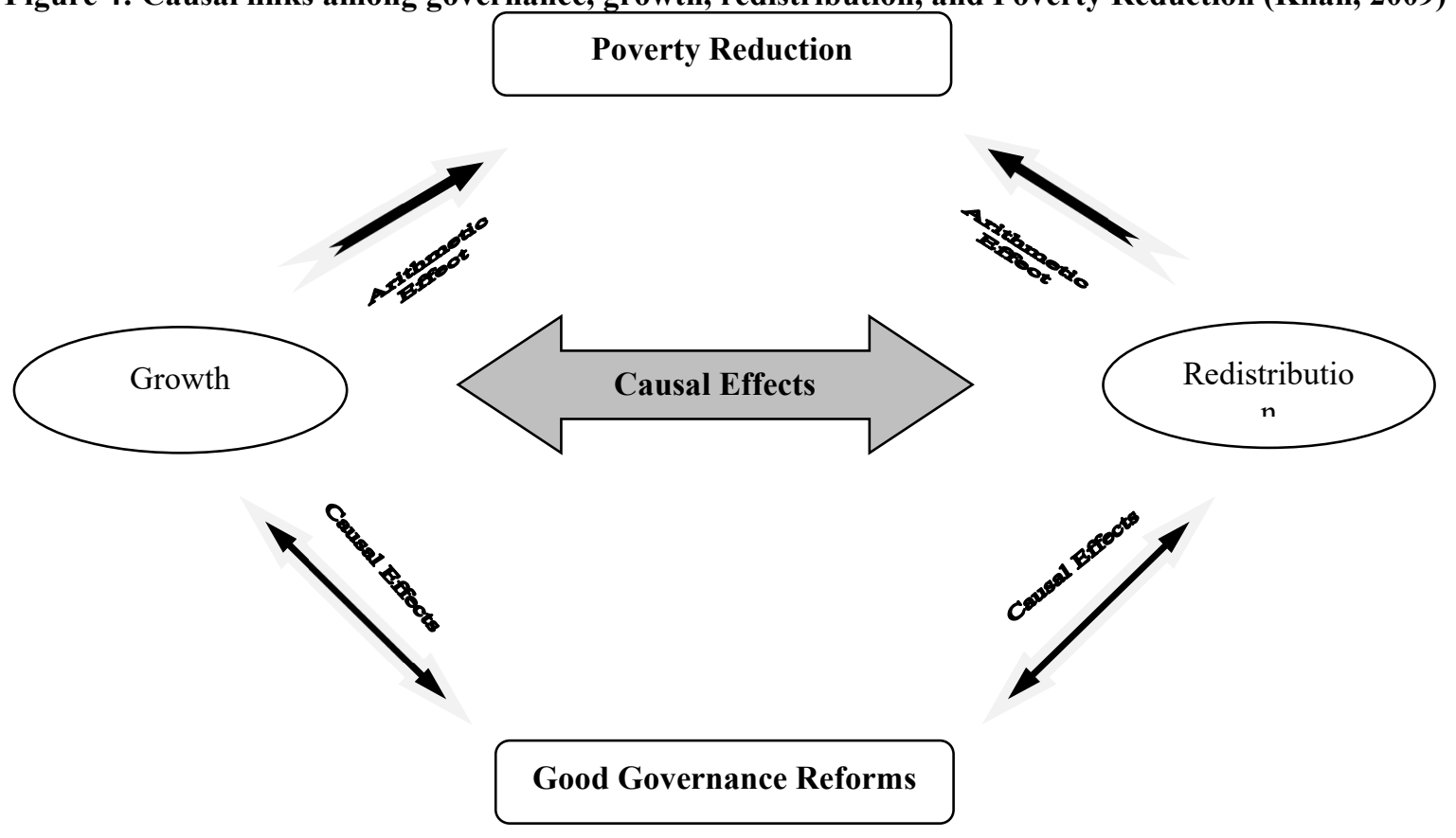

\subsection{Good Governance as Market-enhancing Governance}

Keeping these fundamental questions about the relationship between growth, distribution and poverty in mind, we can look at the important policy area of governance reform to see how these reforms may affect poverty. We can examine this by looking at the possible effects of governance reforms on growth and distribution. Much of the emphasis of good governance reforms has focused on the likely effect of these reforms on growth. The anomalous nature of good governance on growth has been examined elsewhere (Khan, 2007).

Governance reforms refer to strengthening state capabilities to enforce institutional rules that are important for economic and social development. The dominant "Good Governance" paradigm identifies a series of capabilities that, it argues, are necessary governance capabilities for a market-friendly state. These include, in particular, the capabilities to protect stable property rights, enforce the rule of law, effectively implement anticorruption policies and achieve government accountability. Many of these capabilities are clearly desirable as they help to achieve conditions that are desirable. But in the good governance framework, these capabilities are not just desirable for achieving some of the goals of development. Rather, good governance capabilities are identified as preconditions for development because they ensure that markets will be efficient and less subject to market failures (Khan, 2007).

According to Khan 2009, a core proposition ensures that efficient markets are achievable in developing countries, and they will drive development. The inefficiency of markets in developing countries is the source of market failures that constrain development. These inefficiencies are due to high transaction costs in developing country markets, which are, in turn, due to poorly protected property rights and welfare-reducing interventions, in turn, persist because of corruption and rent-seeking, unstable property rights and welfare-reducing interventions persist (some individuals and groups benefit from these instabilities and interventions). And finally, fighting against rent-seeking and corruption continues incessantly because of weak accountability and poor democracy, allowing a minority to gain financial benefits from the majority. 


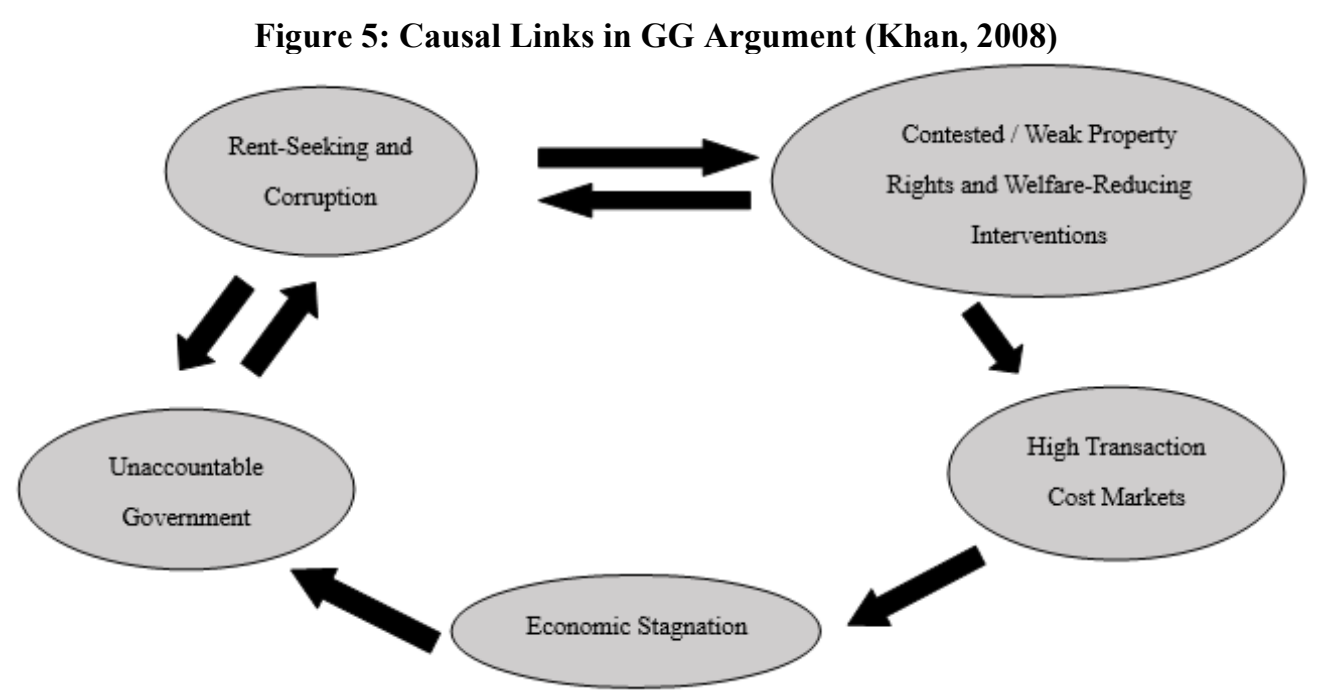

All the states have to achieve capabilities to protect property rights and contracts using the rule of law. These required capabilities for fighting corruption and rent-seeking, in turn, have to be bolstered by reforms which promote democratization, decentralization, and accountability. The final component often added to the package by development agencies is the promotion of Pro-poor service delivery as a way of mobilizing the poor who are the majority or close to the majority in poor countries. If this group can be mobilized to hold the country to account by ensuring that the country has delivered the service to them, then the accountability essential in this framework can be kick-started. The importance of Pro-poor service delivery in this governance approach is therefore not simply the direct effect on reducing poverty, but primarily the establishment of the virtuous cycle of governance which, in theory, would sustain market-led growth (Khan, 2009).

Figure 6: Good Governance Policy Agenda (Khan, 2008)

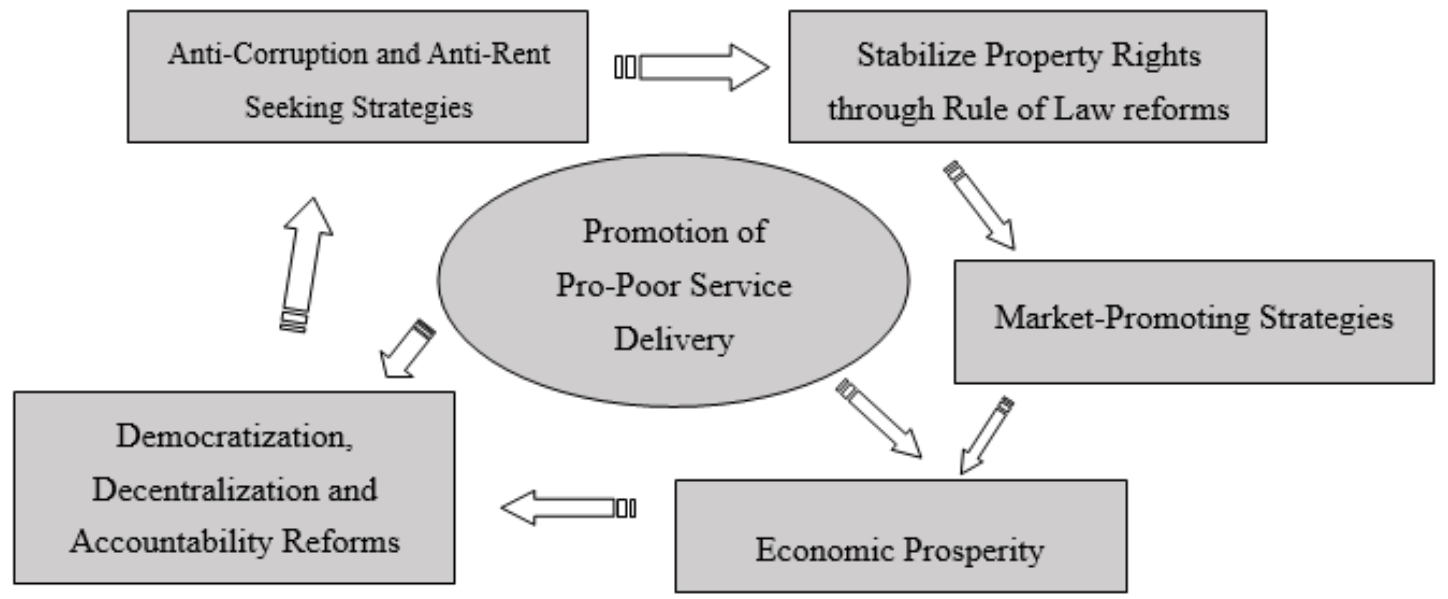

\section{Governance Aspects and Poverty Situation in Cambodia}

\subsection{Cambodia's Governance Historical Background}

The promulgation of the new Cambodia's Constitution in 1993 laid the foundation for the development of Cambodia's new governance system. The Constitution declares liberal democracy and a multi-party system as the foundations of the political regime of the Kingdom of Cambodia. It stipulates that Cambodian citizens exercise their powers through three separate branches: the Legislature, the Executive, and the Judiciary (Figure 7). The Constitution defines a market economy as the foundation of Cambodia's economic system. Ownership of private property such as land is guaranteed under the Constitution.

The Cambodian government has made tremendous efforts to adjust and reform the governance structure towards liberal democracy and a market economy since 1993. New laws were enacted, and a large number of administrative orders were issued to implement these laws. New institutions and organisations were created to carry out important responsibilities in the public sector. Given the enormity of the challenges, Cambodian authorities deserve credit for their efforts and leadership in carrying out the reforms.

Yet, there remains a wide scope for improvement strengthen GG if Cambodia is to sustain equitable growth and development. In this, key issues and challenges are critically examined to take account of four elements of governance such as: accountability, transparency, participation, and predictability (ADB, 1995). 
Figure 7: The Transition of Political, Legal and Economic Systems in Cambodia

\begin{tabular}{|c|c|c|c|c|}
\hline Era Systems & Legal System & Political System & Political Power & Economic System \\
\hline \multirow[t]{2}{*}{ Pre-1953 } & French based civil code & Under the French & Held by French & Colonial Type \\
\hline & and judiciary & Protectorate & & \\
\hline 1953-1970 & French based civil code & Constitution & Held by Prince & Market and then \\
\hline (The Kingdom & and judiciary & monarchy & N. Sihanouk as PM & nationalization \\
\hline \multicolumn{5}{|l|}{ Of Cambodia) } \\
\hline $1970-1975$ & French based Civil Code & Republic & Held by Lon Nol & Market, war \\
\hline (Khmer Republic) & and Judiciary & & & economy \\
\hline $1975-1979$ & Legal system destroyed & All previous systems & s Khmer Rouge & Agrarian, \\
\hline (Democratic & & abolished, extreme & & centrally planned \\
\hline \multirow[t]{2}{*}{ Kampuchea) } & & Maoist agro- & & \\
\hline & & communism & & \\
\hline 1979-1989 (The & Vietnamese-oriented & Communist Party, & Cambodian People & Soviet style \\
\hline People’s Republic & model & central committee & Party & central planning \\
\hline Of Kampuchea) & & and local committee & & \\
\hline 1989-1993 (The & Greater economic & Communist Party, & Cambodian People & Liberalized central \\
\hline State of Cambodia) & rights & central committee & Party & planning \\
\hline & & and local committee & & \\
\hline 1993-Present & French based Civil Code & Constitutional & Shared between & Market Economy \\
\hline (The Kingdom & combined with common & Monarchy & FUNCIPEC and & \\
\hline of Cambodia) & law in certain sectors & & СPP & \\
\hline
\end{tabular}

\section{Source: Cambodia: Enhancing Good Governance for Sustainable Development ADB, 2000}

\subsection{Cambodia's Governance Structure of the Public Sector}

There are three separated powers in Cambodia:

Legislature: bicameral Parliament of Cambodia consists of: Senate (62 seats; 58 indirectly elected by parliamentarians and commune councils, 2 indirectly elected by the National Assembly, and 2 appointed by the monarch; members serve 6-year terms) National Assembly (125 seats; members directly elected in multi-seat constituencies by proportional representation vote; members serve 5-year terms) elections: Senate - last held on 25 February 2018 (next to be held in 2024); National Assembly - last held on 29 July 2018 (next to be held in 2023 ) election results: Senate - percent of vote by party - CPP 96\%, FUNCINPEC $2.4 \%$, KNUP $1.6 \%$; seats by party - CPP 58; composition - men 53, women 9, percent of women 14.5\% National Assembly - percent of vote by party - CPP 76.9\%, FUNCINPEC 5.9\%, LDP 4.9\%, Khmer Will Party 3.4\%, other 8.9\%; seats by party - CPP 125; composition - men 100, women 25, percent of women $20 \%$; note - total Parliament of Cambodia percent of women $18.2 \%$.

Executive: chief of state: King N. Sihamoni (since 29 October 2004) head of government: Prime Minister Samdech Hun Sen (since 14 January 1985); cabinet: Council of Ministers named by the prime minister and appointed by the monarch elections/appointments: monarch chosen by the 9-member Royal Council of the Throne from among all eligible males of royal descent; following legislative elections, a member of the majority party or majority coalition named prime minister by the Chairman of the National Assembly and appointed by the monarch.

Judiciary: highest courts: Supreme Council (organized into 5- and 9-judge panels and includes a court chief and deputy chief); Constitutional Court (consists of 9 members); note - in 1997, the Cambodian Government requested $\mathrm{UN}$ assistance in establishing trials to prosecute former Khmer Rouge senior leaders for crimes against 
humanity committed during the 1975-1979 Khmer Rouge regime; the Extraordinary Chambers of the Courts in Cambodia (also called the Khmer Rouge Tribunal) were established and began hearings for the first case in 2009; court proceeding were ongoing in 2016 judge selection and term of office: Supreme Court and Constitutional Council judge candidates recommended by the Supreme Council of Magistracy, a 17-member body chaired by the monarch and includes other high-level judicial officers; judges of both courts appointed by the monarch; Supreme Court judges appointed for life; Constitutional Council judges appointed for 9-year terms with one-third of the court renewed every 3 years subordinate courts: Appellate Court; provincial and municipal courts; Military Court.

\section{The KING}

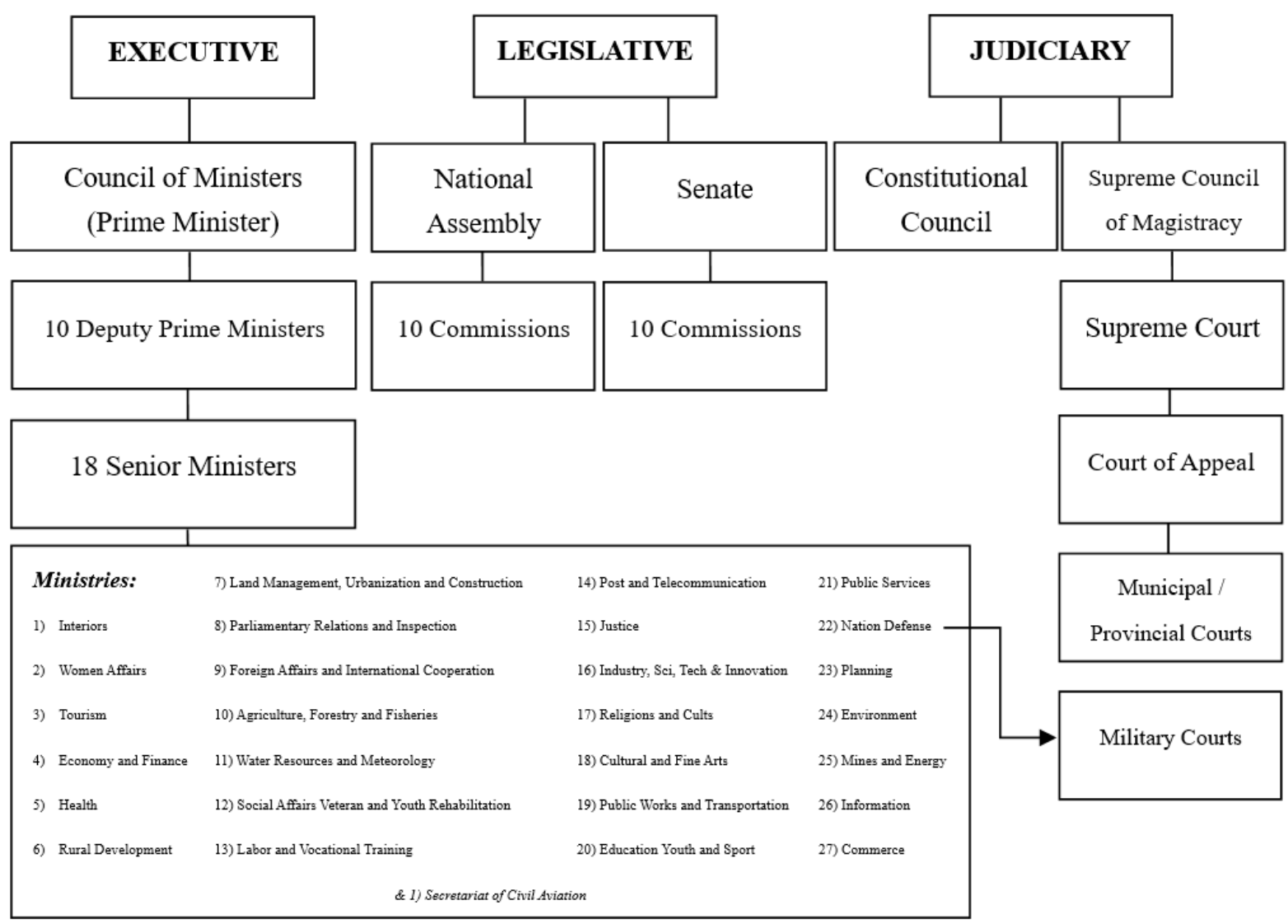

Source: The Royal Government of Cambodia $6^{\text {th }}$ Term (2018-2023) (2020 reform)

\subsection{The Governance Weakness in Cambodia}

There are some of weak governances in Cambodia are perceived through the follow points below:

* The Limited Role in Legislative Process and Shortage of Financial and Human Resource The power to initiate legislation rests jointly with the prime minister and members of the National Assembly and Senate. To date these two bodies have played a limited role in drafting legislation. Most draft legislation originates with the Government of Cambodia. The National Assembly has simply tended to review and enact bills drafted by the Government, often without being given sufficient time and lacking the requisite expertise. Also, the legislature rarely receives copies of regulations or decisions by the Government or ministries related to laws enacted. This contributes to imbalance in the system of checks and balances. This imbalance is partly associated with a shortage of financial and human resources available for the National Assembly and Senate compared with the Government. Such shortages are particularly noticeable with respect to technical and financial expertise. The National Assembly and Senate receive little technical assistance from donors compared with the Government. Ultimately, this will adversely affect the quality of good governance.

* The Lack of Independence in the Judicial System From a governance point of view, an independent Judiciary is vital to a working system of "Checks and Balances" among government branches (Anam, 2002). If the Judiciary is susceptible to pressures from the other branches of power, the Legislature and the Executive are left unchecked, and are unlikely to be accountable to people. The public loses trust in the Judiciary, creating incentives to resolve conflicts in other ways, the rule of law will erode. Although the Cambodian Government recognizes such problem and initial steps have been taken, serious discussions at the national level are needed. 
Cambodia's judicial system is still weak and struggles to deal with the demands placed upon it. Both the civil and military courts are subject to political pressure and allegations of corruption in criminal cases are commonplace. In Chapter 11 of Cambodia's Constitution, the judiciary shall be an independent power, which shall guarantee and uphold impartiality and protect the rights and freedoms of the people. Article 130 of the Cambodia's Constitution 1993, states clearly that "judicial power shall not be granted to the legislative or executive branches of government." According to The Article 134 of the Cambodia's Constitution 1993, the King is the guarantor of judicial independence, assisted by a body called the Supreme Council of Magistracy (SCM), which "shall be established by an organic law which shall determine its composition and functions". Serious questions remain about this council's independence. As in many of Cambodia's institutions, appointees have political affiliations. The SCM has yet to demonstrate that it has either the will or the ability to protect the independence of the judiciary. However, it is the only institution which has the power to take disciplinary actions against judges and prosecutors. The Minister of Justice is also a member of the Council, thus violating the constitutional provisions for the separation of executive and judicial powers in Cambodia. If the decisions of the judiciary are simply intervened by other branches a culture based on the protection of human rights and the rule of law won't be able to develop in Cambodia.

* The High Level of Corruption The issue of corruption is closely linked to the absence of transparency. Corruption exists at all levels in Cambodian society despite government policies and measures to combat and reduce it. The major impediment to reducing corruption is the incomplete implementation of good governance and transparency in Cambodia. The effects of corruption take both concrete and less tangible forms. At the most basic level, corruption results in inefficient management of public resources and governmental decision-making based upon the personal gain of those in positions of power rather than the public welfare. Among the immediate results of this unprincipled behavior in a developing country like Cambodia are such basic things as reduced levels of health, education, and infrastructure. Beyond these immediate effects, corruption corrodes the basis for trust between public officials and the public they are supposed to serve, thus undermining and preventing the further development of the foundations of democracy itself. Thus, for example, the corrupt practice of vote-buying illustrates the commonly held conviction that once candidates are in power, they will act in their own personal interests anyway, so the voter quite reasonably expects little beyond the price of his or her vote. The Government's inability to effectively manage public resources is aggravated by the weak system of public administration, which in turn is partly a result of corrupt hiring and promotion practices based upon patronage and payoffs rather than merit, work output, or success in achieving pronounced government objectives, whether in the realm of poverty reduction or elsewhere. Clearly such a system is incapable of responding to the people's needs, when in fact those needs are even taken into account.

* The Lack of Independent Accountability Institutions The presence of well-functioning independent accountability institutions such as courts and audit offices are the one important prerequisite of good governance. These institutions play a critical role as "Checks and Balances" to the authorities holding power. They contribute significantly to the accountability and transparency of public institutions. Any attempts to fight corruption in the public sector will be extremely difficult unless accountability institutions are in place and carrying out their assigned responsibilities properly. Within the Executive branch, the Cambodian Government has two levels of accountability institutions: (1) a newly established Ministry of Parliamentary Relations and Inspection; and (2) inspection departments within each ministry. Despite their important functions, these institutions have only limited independence at best as institutions within the Executive branch. Thus, one key structural problem in public finance is the lack of an independent audit authority with powers to carry out external audits of the Government.

* Low Salary Scale and Lack of Organizational for Service Delivery The problem of low salaries has a devastating impact on the functioning of the public sector, and spillover effects on other domains such as civil society and media. Likewise, it has serious implications for ongoing public sector reforms since inadequate public salaries affect all sectors. If the low salary scale issue is not addressed properly in the overall reform process, there is a high risk that this will remain a major obstacle to all governance reforms. In the area of public administration, lack of organizational for service delivery is a major structural issue. In addition to raising salaries of civil servants, civil administrative needs sound organizational structures and institutional arrangements if its service delivery is to be more effective and efficient.

* Weakness of Public Administration and Poor Governance GG relates to the efficient management of public resources. In the context of Cambodia, the government's ability to effectively manage public resources is constrained by a weak public administration. The civil service is overstaffed, and there is a low level of technical and managerial capacity. Poor public administration and weak governance have exacerbated uncertainty in the business environment, while embryonic and yet poorly maintained infrastructure keeps operation costs high. Increasingly, labor disputes are adding to the already high costs in the formal sector, deterring foreign investment. It is true that success or failure in the implementation of reforms depends on the quality of governance. Poor governance is the constraint for the healthy growth of the economy, especially of the private sector. Weak governance also means weak state institutions, which constrain the implementation of laws, leading to loss of 
credibility and confidence among investors, businessmen, the international community and also Cambodian citizens in the government.

* High Centralized Administration Structure The Government maintains a highly centralized structure of civil administration. Under current system, provincial governors are appointed by the government. There's no local civil administration directly representing the people. Provincial governments hold little authority for revenueexpenditure decision making. They act merely as administrative units, disbursing expenditures as delegated by relevant line ministries of the central government (World Bank, 1999). Local administration is not given enough financial or managerial autonomy to respond to the needs of local communities. The current centralized civil administration does little to encourage participation of local people or administrators in the decision-making process. This has pointed to the importance of decentralization and de-concentration if the Government is to improve good governance, particularly at local levels. Unfortunately, the current sub-national administration lacks a coherent legal basis. The Constitution of Cambodia says nothing about the powers and responsibilities of provincial, district, commune or village administration. The National Assembly has passed no law on the responsibilities of sub-national administration or government. The only legal texts which exist are various administrative orders such as Sub-Degrees, Prakas, and circulars issued by Office of the Council of Ministers and Ministry of Interior. There have been no elections at the province, district or commune levels to establish locally elected representative bodies.

* Insufficient Funds to Support Decentralization Every country where decentralization has been tried points to the fact that the commune councils will struggle to establish legitimacy if they are insufficiently funded. Decentralization will only address important issues of official corruption and financial mismanagement if commune councils are transparent, and accountable to the people who elected them. Downward accountability for local administration is a new phenomenon in Cambodia, with officials traditionally only accountable upwards to higher levels of government. The proportional representation voting system, and the participation of political parties in commune administration, will do little to promote the downwards-accountability of commune councilors. Accountability and transparency might also be compromised if the unallocated and centrally appointed commune clerks are afforded too much power, or if commune officials use their positions, or the resources of the commune council, for personal benefit. These problems could be significant if systems for resource allocation and distribution are not paid careful attention.

\section{Findings}

\subsection{The Cause of Poverty in Cambodia}

Cambodia is the one country that has a long period of destructive conflict and instability. These are the main root contributor to the widespread poverty that currently exists. Indeed, those who were maimed, displaced, orphaned, or widowed by the conflict face the greatest hardship. Damage infrastructures, land mines, and other security threats contributed to low agriculture production. Execution of educated Cambodians during Khmer Rouge Regime contributed to the low level of human resource that hamper the effective delivery of social and government services.

In Cambodia, population under the poverty line is defined as poor. The Cambodian poor, as defined by low incomes and low consumption bundles, generally tend to have less access to productive resources. 90 percent of the poor belong to households that rely on agriculture as the primary income.

Poverty in Cambodia is characterized by low income and consumption, poor nutritional status, low educational, less access to public services including school and health services, less access to economic opportunities, vulnerability to external shocks, and exclusion from economic, social and political processes.

\subsection{Poverty Indicators in Cambodia}

\section{Where are the poor in Cambodia?}

According to the ADB 2014, the vast majority of the poor live in rural areas. But where are those areas exactly? The official poverty measure can't be used to calculate poverty at the provincial level, but there are several other sources of subnational poverty data, including the Identification of Poor Households (IDPoor) targeting system implemented by the Ministry of Planning and the predictive poverty rates derived from the commune Database (CDB) maintained by the Ministry of Interior. Each system measures different things, so care must be taken in drawing conclusions. For example, IDPoor classifies Koh Kong as having the highest poverty rate, but Koh Kong is not even among the 10 poorest provinces using other measures. Table 1 compares the poorest provinces according to IDPoor, the CDB, and the multidimensional poverty index (MPI). Although the ranking differs for each list, seven provinces appear on all three lists and thus may be considered to be particularly poor: Kampong Chhnang, Kampong Thom, Kratie, Preah Vihear, Pursat, Siem Reap, and Stung Treng. These provinces are around Tonle Sap Lake and in the northeast. 
Table 1: The 10 Poorest Provinces in Cambodia, by Data Source

\begin{tabular}{cllllll} 
& CDB 2012 & & $\begin{array}{l}\text { IDPoor } \\
\text { 2009-2011 }\end{array}$ & & MIPI 2010* \\
\hline Rank & Province & $\%$ & Province & $\%$ & Province & $\%$ \\
1 & Preah Vihear & 37 & Koh Kong & 44 & Mondulkiri & 44 \\
$\mathbf{2}$ & Stung Treng & 37 & K. Chhnang & 37 & Rattanakiri & 44 \\
$\mathbf{3}$ & Rattanakiri & 36 & Kratie & 36 & Preah Vihear & 39 \\
$\mathbf{4}$ & Oddar Meanchey & 34 & Battambang & 34 & Stung Treng & 39 \\
$\mathbf{5}$ & Mondulkiri & 33 & Pursat & 34 & Kratie & 29 \\
$\mathbf{6}$ & Kratie & 29 & Preah Vihear & 32 & Pursat & 25 \\
$\mathbf{7}$ & K. Thom & 28 & Pailin & 32 & K. Thom & 24 \\
$\mathbf{8}$ & Siem Reap & 29 & Siem Reap & 31 & K. Chhnang & 23 \\
$\mathbf{9}$ & Pursat & 28 & K. Thom & 31 & K. Cham & 20 \\
$\mathbf{1 0}$ & K. Chhnang & 28 & Stung Treng & 30 & Siem Reap & 19
\end{tabular}

$\mathrm{CDB}=$ Commune Database, IDPoor $=$ Identification of Poor Households, MPI $=$ multidimensional poverty index.

* This column reports the MPI's severe poverty rate (deprived in more than $50 \%$ of the indicators).

Sources: Ministry of Planning and United Nations Development Programme. 2012. Poverty Reduction by Capital, Provinces, Municipalities, Districts, Khans, and Communes and Sangkats Based on Commune Database 20042012. Phnom Penh: MOP; Ministry of Planning IDPoor database; and Oxford Poverty and Human Development Initiative (OPHI). 2013. Country Briefing: Cambodia. Multidimensional Poverty Index Data Bank. University of Oxford: OPHI.

Source: Cambodia: Country Poverty Analysis 2014 (ADB)

\subsection{Cambodia GDP Annual Growth Rate 2019}

The Gross Domestic Product (GDP) in Cambodia expanded 7.50 percent in 2018 from the previous year. GDP Annual Growth Rate in Cambodia averaged 7.58 percent from 1994 until 2018, reaching an all-time high of 13.30 percent in 2005 and a record low of 0.10 percent in 2009.

$\begin{array}{llllll}\text { Cambodia GDP } & \text { Last } & \text { Previous } & \text { Highest } & \text { Lowest } & \text { Unit } \\ \text { GDP Annual Growth Rate } & 7.50 & 6.90 & 13.30 & 0.10 & \text { percent } \\ \text { GDP } & 24.57 & 22.18 & 24.57 & 0.51 & \text { USD Billion } \\ \text { GDP per capita } & 1205.30 & 1137.80 & 1205.30 & 321.30 & \text { USD } \\ \text { GDP per capita PPP } & 3870.30 & 3653.60 & 3870.30 & 1031.70 & \text { USD } \\ \text { Gross Fixed Capital Formation } & 13213.80 & 12454.80 & 13213.80 & 1525.40 & \text { KHR Million } \\ \text { GDP Constant Prices } & 52956.00 & 49262.00 & 52956.00 & 14175.00 & \text { KHR Billion } \\ \text { GDP From Agriculture } & 9401.20 & 9240.60 & 9401.20 & 4756.90 & \text { KHR Billion } \\ \text { GDP From Construction } & 4394.30 & 3724.40 & 4394.30 & 420.00 & \text { KHR Billion } \\ \text { GDP From Manufacturing } & 11252.60 & 10571.20 & 11252.60 & 1445.50 & \text { KHR Billion } \\ \text { GDP From Mining } & 720.50 & 614.90 & 720.50 & 20.10 & \text { KHR Billion } \\ \text { GDP From Public Admin- } & 523.40 & 495.70 & 523.40 & 318.50 & \text { KHR Billion } \\ \text { GDP From Services } & 19457.20 & 18181.60 & 19457.20 & 4192.90 & \text { KHR Billion } \\ \text { GDP From Transport } & 3248.70 & 3008.50 & 3248.70 & 681.70 & \text { KHR Billion } \\ \text { GDP From Utilities } & 328.40 & 302.30 & 328.40 & 50.80 & \text { KHR Billion }\end{array}$

Table 2: Source: Trading Economics Cambodia GDP Annual Growth Rate 2019

\subsection{The Barriers of the GG in Cambodia}

According to the group discussion, the following points are the important sectors which impede GG of Cambodia such as: Limited power of legislative and judiciary, limited governance of the RGC, limited public administration (public service delivery), and limited NPM. Low HDI, widespread corruption, limited law enforcement, low salary scale for the civil servants, insufficient funds for decentralization and de-concentration, and other causes and political situation effects also contribute to GG's considerable concerns. 
Governance and Political System Indicators of Cambodia

\begin{tabular}{lcccc}
\hline \multicolumn{1}{c}{ Indicators } & From & To & Average & Remarks \\
\hline \hline Rule of Law & 1996 & 2017 & -1.11 & $(-2.5 \mathrm{~W} ; 2.5 \mathrm{~S})$ \\
\hline Government effectiveness & 1996 & 2017 & -0.85 & $(-2.5 \mathrm{~W} ; 2.5 \mathrm{~S})$ \\
\hline Control of corruption & 1996 & 2017 & -1.14 & $(-2.5 \mathrm{~W} ; 2.5 \mathrm{~S})$ \\
\hline Regulatory quality & 1996 & 2017 & -0.43 & $(-2.5 \mathrm{~W} ; 2.5 \mathrm{~S})$ \\
\hline Voice and accountability & 1996 & 2017 & -0.94 & $(-2.5 \mathrm{~W} ; 2.5 \mathrm{~S})$ \\
\hline Political stability & 1996 & 2017 & -0.39 & $100=$ no corruption \\
\hline Corruption perceptions & 2005 & 2018 & 21 & Percent $(\%)$ \\
\hline Women in parliament & 1997 & 2018 & 14.6 & $7 \mathrm{~W}-1 \mathrm{~S}$ \\
\hline Political rights & 1972 & 2019 & 6 & $7 \mathrm{~W}-1 \mathrm{~S}$ \\
\hline Civil liberties & 1972 & 2019 & 6 &
\end{tabular}

Table 3: Source: The Global Economic Indicators 2019. Note: (W=Weak, S=Strong)

\subsection{Governance Reforms Development in Cambodia}

Legal and Judicial Reform Since 2003, the RGC has set out strategies and an action plan in order to bring about legal and judicial reform. Significant achievements including the establishment of various bodies, the creation of legal instruments and increased capacity building have taken place in order to strengthen the judiciary as well as to modernize the system. In spite of this, many challenges remain including (RGC, 20014-2018):

$>$ Human resources:

$>$ - There is a shortage of judges, prosecutors, court clerks, and administrative officials at the Ministry of Justice (MoJ) and municipal and provincial courts.

$>$ - Shortage of qualified special judges in the Labor Court, Juvenile Court, Commercial Court, and Administrative Court.

$>$ - Shortage of registration officials in the court registers (Model Court Project). Institutional capacity management:

$>$ - Shortage of office buildings in the ministry and provincial courts and residences and offices for judges and prosecutors.

$>$ - Shortage of buildings for dispute resolution mechanisms.

$>$ - Limited budget for MoJ and municipal and provincial courts.

- Shortage of lawyers for legal assistance.

- - Shortage of budget for processing criminal cases.

- - Limited transportation for field visits.

The RGC has committed to continue to bring about additional results in accordance with the legal and judicial reform strategies as laid out in 2003. The following are the policy suggestions to accelerate reform.

$>$ Continue to increase resources, both infrastructure and budget, to municipal and provincial courts.

$>$ Continue to increase the capacity and number of judges, prosecutors and judicial officers by recruiting young Cambodians through the judicial academy and providing increased training.

$>$ Continue to strengthen judicial ethics and disciplinary actions against delinquent judges, prosecutors and relevant persons, and to fight corruption.

$>$ Expand and strengthen the services and use of Alternative Dispute Resolution (ADR).

$>$ Increase the number of appeal courts.

$>$ Reduce the number of prisoners by applying an innovative sentencing regime and encouraging the use of ADR (PIC, 2016).

Anti-Corruption The Royal Government of Cambodia (RGC) has a strong commitment to combating corruption. Prioritized policies and programmes on anti-corruption are clearly specified in the Rectangular Strategy Phase I, Phase II and Phase III considering good governance as a core angle and anti-corruption is one of the priorities set. The RGC has supported and endeavoured to have the Anti-Corruption Law adopted along with other relevant laws and regulations for curbing corruption in Cambodia.

In 2010, the Anti-Corruption Law (ACL) was promulgated, and the law was based on the Code of Criminal Procedure and the Criminal Code. The ACL has the purpose to promote the effectiveness of all forms of service delivery and to strengthen good governance and the rule of law as well as to maintain integrity and justice which are fundamental for social development and PR. However, fighting against corruption really needs the participation and support from all stakeholders both from the private and public sectors as well as international cooperation.

To be a truly independent institution, the ACL was amended and promulgated on 1st August 2011, allowing the Anti-Corruption Institution (ACI) to have an independent budget that is separate from the budget of the Office of the Council of Ministers, aiming to ensure that the institution can carry out its mandate effectively. It also provides the President of the National Council against Corruption (NCAC) the right to structure and nominate 
officials from the deputy director at the department level down upon the request made by the President of the ACU.

In 2012, the Public Procurement Law was promulgated, which establishes certain corruption offences and gives absolute competency to the ACU to investigate and file corruption-related cases in the court. In order to succeed in curbing corruption, the NCAC set out a roadmap for ACU in fulfilling its mission to bring more crucial achievements in the five identified areas, namely education, prevention and obstruction, law enforcement, national and international cooperation, and GG and internal control.

According to the strategic plan of the 2nd mandate of the NCAC (2015-2020), the ACU has set out its action plan to focus on three intertwined approaches: education, prevention and obstruction, and law enforcement, which have been supported and encouraged by the government with the participation from the concerned authorities at all levels, the private sector, media, academia and civil society.

Decentralization and Deconcentration Reform The RGC is working to promote a service culture and to enhance the training and skills of public agencies and their staff in order to make public administration effective, efficient, reliable and responsive. Although Cambodia has been historically centralized, there have been some efforts over the years to improve subnational administration. The Law on Provincial and Municipal Budgets and Asset Management 1998 was a particularly important step, defining the basis for a deconcentrated system of nonelected provinces and municipalities to help manage subnational budgets and assets. The law lays out their basic functional responsibilities and assigns considerable tax and nontax revenues to them. This is done, however, in the clear context of a unified administration and budgeting process with strong upward accountability. Budget and financial management authority is given to the (centrally appointed) governors, and their fiscal role is subject to supervision by the Ministry of Economy and Finance. In addition, budget approval is required by the National Assembly in line with the public finance laws and regulations.

According to the EUROPA 2015, the first step towards present decentralization policy--with elements of limited devolution to elected councils--began with the passage of the Commune Sangkat Administrative Management and Commune Sangkat Election Laws in 2001 and follow-up decrees (RGC, 2002). These laws and regulations laid the groundwork for decentralization by providing for local (commune and sangkat--hereafter referred to as commune) elections, allowing the communes to take responsibilities for certain matter and to raise certain revenues, as well as setting up operating mechanisms and procedures. The first local elections were held in February 2002.

In 2005, the government adopted the Strategic Framework for Decentralization and Deconcentration Reforms to expand the initial decentralization (RGC, 2005). The strategic framework outlined two major changes. First, the government declared its intention to maintain direct elections at the commune level but to establish indirectly elected (by commune councilors) government councils at the province/municipality and district/khan levels. The framework also declared that it would empower these councils with functions, resources and capacity to deliver services. Second, these new levels were mandated to adopt unified administrations within their territories aimed at promoting the coordinated development and delivery of public services. This provision in part recognized how difficult it would be to empower the existing small-scale commune councils, but it does state that the higher levels are expected to work closely with communes and help them to assume a greater role in planning, budgeting, service provision and development.

With the passage of Law on Administrative Management of Capital, Provinces, Municipalities, Districts and Khans in 2008, Cambodia took the next step in decentralization reform. Broadly following the strategic framework, the law empowers new levels of subnational government and reaffirms the importance of the existing commune/sangkat councils. This law also formally establishes unified administrations for each level as per the strategic framework, mandates mechanisms for public consultation, participation, equity, transparency and accountability, and creates a strong implementing authority to oversee implementation.

Since many details were undefined by the 2008 legislation, it was left to the National Program for Subnational Democratic Development (NP-SNDD) to create a framework, process and policies for reform at all levels of government and to guide development partners - national and international agencies and NGOs-to adopt common strategies and more harmonized approaches to support decentralization (NCDD, 2010). This is all being done under the authority of the National Committee for Democratic Development of Subnational Administrations (NCDD), which was established in 2008 to manage the overall reforms. NCDD is the fruitful successor of several previous national bodies charged with managing various stages of decentralization reforms.

\section{Analysis}

The results of this study founded that GG is the most powerful stimulus to deal with PR in Cambodia. Thus, we noticed that in 2004 Cambodia had a significant changed by applying Rectangular Strategy that GG is core of the strategy. There's evidence that Cambodia has enjoyed a steady increase of averaged 7.58 \% from 1994 until 2018 (Trading Economics, 20019). The particular documents are examined for the finding of key concepts and the meanings of the linking between GG and PR. The meanings such as:

* Accountability, can be promoted through mechanisms for requiring that responses be made in respect of 
institutional conduct, and through appropriate incentives, good supervision, and high levels of citizen participation;

* Transparency, can be promoted by regular publication and dissemination of information, as well as through enhanced feedback loops among citizens, officials, and policy makers;

* Participation, can be promoted through mechanism that enable citizens to be more involved in the conduct of government, particularly through the implementation of appropriate decentralization policies; and

* Predictability, can be promoted through consistent application of rules and policies.

Through the group discussion on the term of GG and its concepts provided by with some respondents, scholars, and government officials focuses on the linking between GG and PR; and tries to match the four pillars of GG to the PR. Last but not least, it presents Cambodia's vision of GG and its development objectives; and examines the current development of governance reforms, and addresses some potential strategies which the RGC should implement to reduce the poverty problems.

\section{Recommendations and Conclusion 6.1 Recommendations}

The failures of transparency and accountability and the slow progress towards the rule of law represents a serious failure of GG for which Cambodia's poor pay a heavy price. The poor have suffered the most from physical insecurity and lack of access to justice. Poor of governance weakens the ability of the state to deliver basic public goods, for example essential services that are crucial to the investments needed in the human capital of the poor. The poor are particularly helpless in the face of corruption. They depend disproportionately on public goods and are often unaware of what they are required to pay for public services, allowing the corrupt to trade on their ignorance. Such poor governance has led to a slight declination of poverty in Cambodia over the few decades. This trend is encouraging, and a number of challenges will need to be addressed in the years to come. For Economic, there is a need to ensure that the growth process is increasingly pro-poor, generating benefits for those in most need. For Politic, all necessary reforms must be pursued, along with the decentralization process. On the social front, measures of effective social protection need to be strengthened and human capacities reinforced. More than that, institutional changes must be pursued to strengthen the role of civil society and the private sector in the development process and GG effectively mainstreamed in public life. It is clear that poverty and hunger eradication require a better management, sound strategies and multi- faceted response incorporating economic, social as well as political issues.

\subsection{Conclusion}

This study has highlighted some of the critical issues of governance that can positively or negatively impact the process of development in Cambodia. It also underlines the fact that reform is a long-term process that requires setting achievable goals, producing tangible results and mobilising sources of consistent support. While many challenges of GG lie ahead, the commitment to the reform process demonstrated by the government and the achievements made to date are heartening and can serve as the foundation for managing the tasks ahead.

The RGC well recognizes the importance of GG for PR that implementing reform of governance must be one of the key strategies for promoting the economic growth and creating the resources for PR, and it requires extensive reforms with a sustained emphasis on strengthening accountability through the public administration reform, promoting inclusiveness through participatory planning process, fostering predictability through appreciate legal frameworks and instilling a general method of operation of information disclosure and openness to establish transparency.

\section{References}

Abdellatif, A. M. (2003, May). Good governance and its relationship to democracy and economic development. In Global Forum III on Fighting Corruption and Safeguarding Integrity, Seoul (Vol. 20, p. 31). Agere, S. (2000). Promoting good governance: Principles, practices and perspectives (Vol. 11). Commonwealth Secretariat.

Anam, M. (2002). The media and development in Bangladesh. The right to tell: The role of mass media in economic development, 267-74.

Anyang'Nyong'o, P. (2001). Governance and poverty reduction in Africa. African Development Bank.

Brinkerhoff, D. W., \& Goldsmith, A. A. (2005). Institutional dualism and international development: A revisionist interpretation of good governance. Administration \& Society, 37(2), 199-224.

Cambodia, T. N. (2014, December 29). The National Assembly of Cambodia. Retrieved December 29, 2014, from http://en.national-assembly.org/

Cambodia, T. R. (2004-2008; 2008-2013; 2013-2018). The Royal Goverment of Cambodia. Retrieved 2013, from The Rectangular Strategy of Cambodia: http://www.ilo.org/asia/info/research-anddata/WCMS_100515/lang-en/index.htm

Development Forum/National Graduate Institute for Policy Studies. 
Gisselquist, R. M. (2012). Good governance as a concept, and why this matters for development policy (No. 2012/30). WIDER Working Paper.

Graham, J., Plumptre, T. W., \& Amos, B. (2003). Principles for good governance in the 21st century. Ottawa: Institute on governance.

Kato, T., Kaplan, J. A., Sophal, C., \& Sopheap, R. (2000). Cambodia: Enhancing governance for sustainable development. Manila: Asian Development Bank, 43.

Kato, Toshi, Chan Sophal, and Long Vou Pishet (September 1998). Regional Economic Integration for

Khan, M. (2008). Governance and development: the perspective of growth-enhancing governance. GRIPS Kingdom of Cambodia 2000. Second Five-Year Socio-economic Development Plan 2001-2005 (SEDP I). Phnom Penh: Ministry of Planning.

Knack, S., \& Keefer, P. (1997). Does social capital have an economic payoff? A cross-country investigation. The Quarterly journal of economics, 112(4), 1251-1288.

Landell-Mills, P., \& Serageldin, I. (1991). Governance and the external factor. The World Bank Economic Review, 5(suppl_1), 303-320

Lewis, D. J. (1996). Corruption in Bangladesh: discourse, judgements and moralities. Occasional Paper, 5 , 96.

National Poverty Reduction Strategy Paper Joint Staff Assessment Published: Friday, October 10, 2003. Nary, Ms. (2016). Parliamentary Institute of Cambodia. Legal and Judicial Reform in Cambodia.

Niazi, T. H. (2011). Deconcentration and decentralization reforms in Cambodia: Recommendations for an institutional framework. Asian Development Bank.

Onyejekwe, O. (May 2004). The Role of Good Governance in the National Implementation of the BPOA: The Need for a Capable State. the Workshop for the National Focal Points on the Implementation of the Brussels Programme of Action for the Least Developed Countries (p. 14). New York: Brussels Programme of Action for the Least Developed Countries.

Oudom, M. Best Practices in Anti-Corruption in the Kingdom of Cambodia.

Paul, S. (2015). Quality Support Facilities in the Field of Decentralization, Local Governance \& Local Development. Decentralization in Cambodia. EUROPA.

Paul, S. (2015). Quality Support Facilities in the Field of Decentralization, Local Governance \& Local Development. Decentralization in Cambodia. EUROPA.

Porta, R. L., Lopez-De-Silane, F., Shleifer, A., \& Vishny, R. W. (1996). Trust in large organizations (No. w5864). National Bureau of Economic Research.

Prime Minister Hun Sen and the Third Legislature of the National Assembly, at the Office of the Council of Ministers, Phnom Penh, 16 July $2004 .$.

Royal Government of Cambodia (2004): Rectangular Strategy for Growth., Employment, Equity and Efficiency in Cambodia,

Second draft NPRS Annual Progress Report 30 December, 2003

Security, G. (2012, May). Cambodia under Sihanouke 1953-1970. Retrieved November 10, 2013, from Global Security .org: http://www.globalsecurity.org

Shah, A. (2013, January 07). Global Issue. Retrieved December 31, 2014, from http://www.globalissues.org/article/26/poverty-facts-and-stats UN. (2013). United Nation Global Issues. Retrieved November 05, 2013, from United Nation Global Issues: www.un.org/en

Siddequi, Kamal, "General issues cutting Across the Bureaucracy", Towards good governance in Bangladesh, University press limited, p.15 1996.

Sophal, C., Kato, T., Piseth, L. V., Kaplan, J., Nhem, K., Robertson, J., \& Pohoresky, H. (1998). Cambodia: Challenges and Options of Regional Economic Integration. a Conference. Phnom Penh, Cambodia.

Sumarto, S., Suryahadi, A., Arifianto, A., Sadler, K., \& Akhmadi, N. (2004). Governance and poverty reduction: Evidence from newly decentralized Indonesia. Asian Development Experience Vol. 2: The Role of Governance in Asia, 2, 27.

Sustainable Development in Cambodia. Working Paper 5. Phnom Penh, CDRI.

Ter Haar, G. (2000). Rats, cockroaches and people like us: views of humanity and human right.

UK Department for International Development, Making Government Work for Poor People, June 2000.

UNDP, Report on the Workshop on Governance for Sustainable Development, MDGD, New York, April 1996.

UN document CCPR/C/81/Add.12 Initial Reports of States parties due in 1993: Cambodia. 23 September 1998.

WB (1989) Sub-Saharan Africa: From Crisis to Sustainable Growth: A Long-Term Perspective Study, Washington, DC.

WB (1994) Governance: The World Bank’s Experience, Washington, DC: World Bank.

WB (2000) Poverty Reduction Strategy Sources Book. 